\title{
Energy Demand and Interfuel Substitution in the Combined Residential and Commercial Sector
}

Wen S. Chern 


\section{DISCLAIMER}

This report was prepared as an account of work sponsored by an agency of the United States Government. Neither the United States Government nor any agency Thereof, nor any of their employees, makes any warranty, express or implied, or assumes any legal liability or responsibility for the accuracy, completeness, or usefulness of any information, apparatus, product, or process disclosed, or represents that its use would not infringe privately owned rights. Reference herein to any specific commercial product, process, or service by trade name, trademark, manufacturer, or otherwise does not necessarily constitute or imply its endorsement, recommendation, or favoring by the United States Government or any agency thereof. The views and opinions of authors expressed herein do not necessarily state or reflect those of the United States Government or any agency thereof. 


\section{DISCLAIMER}

Portions of this document may be illegible in electronic image products. Images are produced from the best available original document. 
Printed in the United States of America: Available from

National Technical Information Service

U.S. Department of Commerce

5285 Port Royal Road, Springfield, Virginia 22161

Price: Printed Copy \$4.00; Microfiche $\$ 2.25$

This report was prepared as an account of work sponsored by the United States Government. Neither the United States nor the Energy Research and Development Administration/United States Nuclear Regulatory Commission, nor any of their employees, nor any of their contractors, subcontractors, or their employees, makes any warranty, express or implied, or assumes any legal liability or responsibility for the accuracy, completeness or usefulness of any information, apparatus, product or process disclosed, or represents that its use would not infringe privately owned rights. 
Contract No. W-7405-eng-26

ENERGY DIVISION

ENERGY DEMAND AND INTERFUEL SUBSTITUTION IN

THE COMBINED RESIDENTIAL AND COMMERCIAL SECTOR

Wen S. Chern

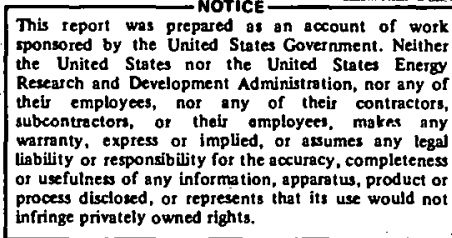

This report was prepared ar

The United States not the Unitad States Energ

Research and Development Administration, nor any of

sponsibility for the accuracy, completeness

process disclosed, or represents, that its use would not

infringe privately owned rights.

\begin{abstract}
SEPTEMBER 1976
Work supported by the Energy Research and Development Administration
\end{abstract}

OAK RIDGE NATIONAT, LABORATORY

Oak Ridge, Tennessee 37830

operated by

UNION CARBIDE CORPORATION

for the

ENERGY RESEARCH AND DEVELOPMENT ADMINISTRATION

OT $W-7405-E N G-26$ 
THIS PAGE

WAS INTENTIONALLY

LEFT BLANK 


\section{Acknowledgements}

The author expresses gratitude to David A. Pilati of the University of Illinols for many useful suggestions during the entire stage of developing this model. Kenneth W. Costello of the Argonne National Laboratory, Richard E. Just of the University of California at Berkeley, Jerry A. Hausman of the Massachusetts Institute of Technology, Anthony G. Lawrence of the Electric Power Research Institute, G. S. Maddala of the University of Florida, and Lester D. Taylor of the University of Arizona provided many valuable comments in reviewing an earlier version of this report. To them I am grateful. I am also indebted to my colleagues, Roger S. Carlsmith, William Fulkerson, Gurmukh S. Gill, Eric Hirst, and Patricia Rice for their helpful comments on the report. Many thanks are due to Pat Love, Debbie Barker, and Sharon Clark for typing several drafts and to A. W. Switzler for editing the final draft of this report. 


\section{THIS PAGE}

\section{WAS INTENTIONALLY \\ LEFT BLANK}


$\underline{\text { Abstract }}$

This paper presents an integrated energy-demand model for the combined residential and commercial sector. The model consists of two parts: the first determines aggregate demand for energy, and the second estimates market-shares for electricity, natural gas, and petroleum products. Demand elasticities for aggregate as well as individual fuels are analytically derivable. The study concludes that pricing strategies can be effective in stimulating the conservation of energy. Furthermore, raising prices of petroleum products and natural gas has greater potential for conservation of end-use energy than raising electricity prices. However, when the primary sources of energy are considered, the results show that raising the prices of electricity is far more effective for energy conservation than raising the prices of natural gas and petroleum products. This practice is more effective because the overall efficiency of fuel use is lower when electricity is employed as the end-use energy form. 
THIS PAGE

\section{WAS INTENTIONALLY LEFT BLANK}


Abstract . . . . . . . . . . . . . . . . . . iii

1. Introduction . . . . . . . . . . . . . . . 1

2. The Market Shares Approach . . . . . . . . . . 5

3. Regression Results and Demand Elasticities . . . . . 8

4. Demand and Conservation of Primary Energy . . . . . . 18

5. Conclusions . . . . . . . . . . . . . . 22

Appendix A: Data ................. . . 25

Appendix B: Comparison of the Fistimated Elasticities for

Alternative Assumptions on End-Use Efficiency . . . . . . 27

Footnotes and References . . . . . . . . . . . 30 


\section{Introduction}

The degree to which increases in energy price stimulate conservation of energy is still an unresolved issue. Most energy demand studies dealing with a single fuel offer only partial answers to this important question. For example, in electricity demand, abundant evidence shows the existence of a significant own-price elasticity. One obvious implication (as Chapman et al. ${ }^{1}$ illustrated) is that a substantial reduction in electricitydemand growth may be anticipated as a result of increases in the real price of electricity. It is not so obvious, however, that increases in elertricity price would reduce total energy consumption after the allowance for interfuel substitution is made.

To evaluate the ultimate impacts of various energy pricing policies, we need an integrated model that treats demands for all substitute fuels interdependently. The purpose of this paper is to construct such an integrated energy-demand model for the residential/commercial sector. Specifically, a market-shares model is developed in which demand elasticities for aggregate as well as individual fuels are analytically derived.

In 1972 the household and commercial sectors used $19 \times 10^{18}$ joules of energy in the United States (Table 1). The largest proportion of energy use was provided by natural gas, which accounted for $42 \%$ of the total. On the other hand, use of coal was almost negligible. Since utilization efficlencies vary remarkably among fuels, it is important to take into account these differences when comparing the relative shares of individual fuels. For space heating, Hise and Holman ${ }^{2}$ show that existing gas furnace systems have utilization efficiencies of 50 to $60 \%$, depending upon the type of furnace and installation. $0 i 1$ furnace systems are slightly less efficient 
Table 1. Quantities and shares of end-use consumption of fuels in the residential/commercial sector, United States, 1972

\begin{tabular}{|c|c|c|c|c|}
\hline \multirow[b]{2}{*}{ Fuel } & \multicolumn{2}{|c|}{ Before adjustment $t^{a}$} & \multicolumn{2}{|c|}{ After adjustment ${ }^{b}$} \\
\hline & $\begin{array}{c}\text { Quantity, } \\
10^{18} \text { joules }\end{array}$ & $\begin{array}{l}\text { Share, } \\
\text { percent }\end{array}$ & $\begin{array}{l}\text { Quantity, } \\
10^{18} \text { joules }\end{array}$ & $\begin{array}{r}\text { Share, } \\
\text { percent }\end{array}$ \\
\hline Electricity & 3.67 & 19 & 3.67 & 31 \\
\hline Natural gas & 8.06 & .42 & 4.43 & 38 \\
\hline Petroleum products & 7.11 & 37 & 3.56 & 30 \\
\hline Coal & 0.27 & $\underline{2}$ & 0.09 & 1 \\
\hline Total & 19.11 & 100 & 11.75 & 100 \\
\hline
\end{tabular}

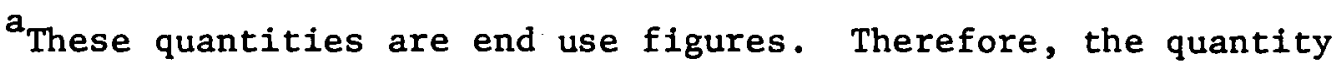
of electricity does not include power plant losses, and the quantities of natural gas, petroleum products, and coal do not include energy used for drilling or mining and distribution.

${ }^{b}$ Assumes a conversion efficiency factor of 1.0 for electricity, 0.55 for natural gas, 0.5 for petroleum products, and 0.35 for coal.

Coriginal data in British thermal units were converted to joules. One Btu equals 1054.8 joules.

Source: U.S. Bureau of Mines, Fuel and Energy Data, United States by States and Regions, 1972, information circular 8647, 1974 . 
than gas furnace systems. Utilization efficiency of coal for home heating is much less than that of ofl and natural gas.

Most of the past studies concerning end-use efficiency have dealt with space heating. Since the bulk of natural gas and petroleum products was used for space heating, the relative end-use efficiencies of space heating are used as proxies for converting the aggregate energy use in the residential/comercial sector into an end-use basis. Because of the potential. blas in applying these approximate efficiency factors, a sensitivity analysis for evaluating this bias was conducted and is discussed in Section 4 and Appendix B. Based on the published sources 2,3 and on consultations with engineers, we selected efficiency factors of 1.0 for electricity, 0.55 for natural gas, 0.5 for oil, and 0.35 for coal as our base case. In applying these factors, original fuel consumption figures of Table 1 were adjusted to an end-use basis and are shown in the second column. These adjustments increase the share of electricity significantly, even though natural gas still constitutes the largest share. Since changes in fuel mix may result in shifting from inefficient to more efficient fuels, in addition to changes in relative fuel prices, it is important to account for these relative efficiencies in estimating interfuel substitution. Historically, electricity prices have been higher than those for natural gas, oil, and coal. In 1972 the average price of electricity was $\$ 6.29$ per trillion joules, while prices of natural gas and No. 2 oil were $\$ 1.04$ and $\$ 1.15$ respectively (Table 2). After adjusting for relative utilization efficiencies, electricity still costs more than natural gas and oil (Table 2). These relative prices are important for explaining the behavior of households and commercial firms in their fuel choices. 
Table 2. Average prices of fuels used in the residential/commercial sector, United States, 1972

\begin{tabular}{|c|c|c|}
\hline Fue1 & $\begin{array}{c}\text { Average price } \\
\text { before adjustment }{ }^{a} \\
\text { dollars } / 10^{9} \text { joules }\end{array}$ & $\begin{array}{l}\text { Average price } \\
\text { before adjustment } \\
\text { dollars } / 10^{9} \text { joules }\end{array}$ \\
\hline Electricity & 6.29 & 6.29 \\
\hline Natural gas & 1.04 & 1.89 \\
\hline No. 2 oil & 1.15 & 2.30 \\
\hline Coal & $0.30^{c}$ & 0.86 \\
\hline Weighted average & $2.06^{\mathrm{d}}$ & $3.37^{e}$ \\
\hline
\end{tabular}

${ }^{a}$ Average prices in their common units are 22.6 mills per kWhr of electricity, $\$ 2.06$ per MCF of natural gas, $17 \mathrm{c}$ per gallon of No. 2 oil, and $\$ 7.66$ per ton of coal.

${ }^{b}$ Assumes a conversion efficiency factor of 1.0 for electricity, 0.55 for natural gas, 0.5 for oil, and 0.35 for coal.

c Based on f.o.b. value.

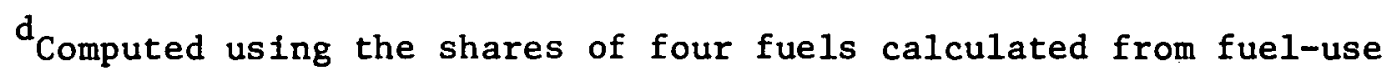
quantities as the weighting factors.

e Computed using the shares of four fuels calculated from end-use quantities as weighting factors. 


\section{The Market Shares Approach}

One common approach to modeling energy demand is estimating a conventional demand function for a particular form of energy and investigating interfuel substitutions by including the prices of substitute fuels in the model. But this approach does not explicitly take into consideration interrelationships between consumption of a particular fuel and consumption of other fuels. The market-share approach developed here treats consumption of all substitutable fuels interdependently. The model consists of two parts: the first determines aggregate demand for energy in all forms, and the second estimates market-shares for three major fuels (electricity, natural gas, and petroleum products). 4

Aggregate energy demand is assumed to be a function of the weighted average energy price, personal income, and the numbers of heating and cooling degree days. The regression equation is expressed in linear form as follows:

$$
\begin{aligned}
& Q=a_{0}+a_{1} P+a_{2} I+a_{3} H+a_{4} C+a_{5} D \\
& \text { where } P=\sum_{i=1}^{3} P_{1} S_{1}, \\
& S_{i}=\frac{Q_{1}}{Q}, \text { and } \\
& a_{i} \text { 's are parameteres to he estimater. }
\end{aligned}
$$

The market share for the $i^{\text {th }}$ fuel is assumed to be a function of 1 ts price, prices of substitute fuels, personal income, and degree days. The three market share equations have the following general expresssion: 
$S_{1}=a_{i 0}+a_{i 1} P_{1}+a_{i 2} P_{2}+a_{i 3} P_{3}+a_{i 4} I+a_{i 5} H+a_{16} C+a_{i 7} D$

for

$1=1,2,3$

where $a_{i j}$ 's are parameters to be estimated.

All variables are defined below:

$Q_{1}=$ End-use quantity of electricity demanded per capita in the residential and commercial sectors $\left(10^{18}\right.$ joules).

$Q_{2}=$ End-use quantity of natural gas demand per capita in the residential and commercial sectors $\left(10^{18}\right.$ joules).

$Q_{3}=$ End-use quantity of petroleum products demanded per capita in the residential and commercial sectors $\left(10^{18}\right.$ joules $)$.

$Q=Q_{1}+Q_{2}+Q_{3}=$ Total end-use quantity of energy demanded per capita $\left(10^{18}\right.$ joules).

$P_{1}=$ Real average price of electricity used in the residential and commercial sectors (dollars $/ 10^{9}$ joules).

$\mathrm{P}_{2}=$ Real average price of natural gas used in the residential and commercial sectors. (dollars $/ 10^{9}$ joules). $P_{3}=$ Real retail price of No. 2 fuel oil (dollars $/ 10^{9}$ joules).

$I=$ Real per capita income (thousands of dollars).

$\mathrm{H}$ = Annual heating degree days weighted by population.

$\mathrm{C}=$ Annual average cooling degree days.

D = Dummy variable having value of 1 for 1971 and 0 for 1972 .

All quantity variables $\left(Q_{i}\right)$ and price variables $\left(P_{i}\right)$ were adjusted according to the approximate relative end-use efficiencies of the three 
fuels as follows:

$Q_{i}=n_{1} q_{i}$

and

$P_{i}=P_{i} / n_{i}$,

where $q_{1}$ and $p_{1}$ are, respectively, reported quantities and market prices, and $\eta_{i}$ are the efficiency factors ( 1.0 for electricity, 0.55 for natural gas, and 0.5 for petroleum products).

The linear form is used because of the inclusion of degree days as variables. From engineering calculations, net heat loss from buildings is approximately proportional to the difference in temperature between the inside and the outside. Both theoretical considerations and direct observation indicate that fuel consumption for heating and cooling varies linearly with degree days when other factors are held constant. 5 Therefore, the use of the linear spectfication which preserves this important engineering relationship is necessary.

Recently, Nissen and Knapp ${ }^{6}$ and Baughman and Joskow ${ }^{7}$ have also estimated a two-component model similar to the one developed in this paper. Baughman and Joskow estimated a set of multinomial logit functions. Their model speriftcation imposes a very restrictive assumption (i.e., all cross-price elasticities with respect to a given price are restricted to be identical). 8 Although Nissen and Knapp also estimated fuelsplit (share) equations, our model differs from theirs in many respects. First, we use quantity shares rather than revenue shares as weighting factors for computing the weighted average price of energy. Our formulation, thus, provides a direct linkage between aggregate demand and market shares. More important, it facilitates the analytical derivation 
of demand elasticities as discussed in Section 3. Second, income and degree-day variables appear in both aggregate-demand and share equations in our formulation. In the Nissen-Knapp model, no climatic variable was introduced, and income appeared only in the aggregate-demand equation. Finally, we adopt a linear spectfication; they used a log-linear specification. Under a linear specification, the fact that the market shares must sum up to one implies that

$$
\sum_{i=1}^{3} a_{i 0}=1
$$

and

$$
\sum_{i=1}^{3} a_{i j}=0 \text { for } j=1, \ldots, 7
$$

The sum of all constant terms in the market-share equations must equal unity, and the sum of the estimated coefficients for each varlable must equal zero. These important properties cannot be easily imposed in the log-linear model used by Nissen and Knapp.

\section{Regression Results and Demand Elasticities}

The system of equations shown in Eq. (2) fits the general speclfication used by Zellner ${ }^{9}$ for seemingly unrelated regressions. A proper procedure to estimate this set of share equations subject to constraints expressed in Eqs. (4) and (5) is Zellner's generalized least-squares approach. One difficulty arises; since all shares sum to unity, the disturbances across the three share equations will always add up to zero for each observation. As a result, the variance-covariance matrix is singular and nondiagonal. Berndt and Wood ${ }^{10}$ 
encountered the same problem in their study of Industrial demand for energy in which translog cost functions were used. They arbitrarily dropped one equation and estimated the remaining equations with linear restrictions with the iterative three-stage least-squares procedure. Unfortunately, this method could not be applied here because the constraints implied in our model are no longer needed when one share equation is dropped. Thus, if only two out of the three share equations are estimated, Zellner's estimation procedure reduces to ordinary least squares (OLS), since we have the same set of independent variables. Hence, the present model. is a special case of the Zellner's model that conforms to the classical multivariate regression model. ${ }^{11}$ In this case, OLS gives efficient estimators because the covariance matrix factors out of the Kronecker product relationships (disregarding constraints). Furthermore, since the constraints are automatically satisfied by oLS (as shown by Pindyck and Rubinfeld ${ }^{12}$, the oLs estimators must be efficient whether constraints are imposed in the multivariate regression or not. It is concluded, therefore, that oLs is the best method for estimating Eq. (2) alone.

To estimate the model as specified in the previous section, complete data on the consumption of all energy sources must be avallable. Data on oil consumption by sector are particularly lacking. Fortunately the U.S. Bureau of Mines recently compiled detailed data on consumption of oil and other fuels on a state basis. Data for 48 states for both 1971 and 1972 were used for estimation in the present study. Although the residential and commercial sectors have to be combined, we believe this set of data is the best available so far. Details of the sources of 
data are discussed in Appendix A.

The regression results are presented in Table 3 . The overall performance of the model is remarkably good in terms of signs and statistical significance of the estimated coefficients. $R^{2}$ 's are reasonably high because this is essentially a cross-sectional analysis. ${ }^{13}$

Results for aggregate demand (Eq. 1.0 in Table 3) show that energy price and income coefficients are statistically significant. Furthermore, the coefficients of degree days all have the expected positive sign, and the heating degree day variable is more significant than the cooling degree day variable.

The coefficient estimates in the market-share equations are all plausible. All own-price and cross-price coefficients have the expected signs and are statistically significant. With respect to income effects, results show that an increase in income would increase market shares for electricity and natural gas and reduce the share for petroleum products. For heating degree days, the results suggest that the share of petroleum products in colder states is higher than the shares of natural gas and electricity. On the other hand, the results show that higher cooling degree days increase the share of electricity while reducing the shares of natural gas and petroleum products. These results are, of course, obvious, because electricity is the major fuel used for air conditioning. The estimated coefficients for the dumm variable indicate that relatively more electricity was used in 1972 than in 1971. This increase may reflect a switch toward electricity because of the uncertainty about the assured availability of oil and natural gas. 
Table 3. Est1mated aggregate demand and market $\varepsilon$ hare equations ${ }^{a}$

\begin{tabular}{|c|c|c|c|c|c|c|c|c|c|c|c|c|c|}
\hline $\begin{array}{l}\text { Eq. } \\
\text { No. }\end{array}$ & $\begin{array}{l}\text { Type } \\
\text { of } \\
\text { fuel }\end{array}$ & $\begin{array}{l}\text { Dep. } \\
\text { var. }\end{array}$ & $\begin{array}{l}\text { Energy } \\
\text { price, } \\
\quad \text { P. }\end{array}$ & $\begin{array}{c}\text { Elect. } \\
\text { prtce, } \\
P_{1}\end{array}$ & $\begin{array}{c}\text { Gas } \\
\text { price, } \\
\mathrm{P}_{2}\end{array}$ & $\begin{array}{c}011 \\
\text { price } \\
\mathrm{P}_{3}\end{array}$ & $\begin{array}{c}\text { Income } \\
\text { I }\end{array}$ & $\begin{array}{c}\text { Heating } \\
\text { degre } \\
\text { days, } \\
\text { H }\end{array}$ & $\begin{array}{c}\text { Cooling } \\
\text { degree } \\
\text { days, } \\
C\end{array}$ & $\begin{array}{l}\text { Yearly } \\
\text { dummy, } \\
\text { D }\end{array}$ & Constant & $\mathbf{R}^{2}$ & D.F. \\
\hline 1.0 & $\begin{array}{l}\text { Total } \\
\text { demend }\end{array}$ & $Q$ & $\begin{array}{l}-12651^{d} \\
(2119)\end{array}$ & . & & & $\begin{array}{l}6.255^{\mathrm{d}} \\
(1.99)\end{array}$ & $\begin{array}{l}3.736^{c} \\
(0.79)\end{array}$ & $\begin{array}{r}4.287 \\
(2.46)\end{array}$ & $\begin{array}{l}-1561 \\
(1660)\end{array}$ & $\begin{array}{c}50060^{d} \\
(12300)\end{array}$ & 0.617 & 90 \\
\hline 2.1 & $\begin{array}{l}\text { Elect. } \\
\text { share }\end{array}$ & $\begin{array}{c}Q_{1} / Q \\
\times 1000\end{array}$ & & $\begin{array}{r}-75.04^{d} \\
(6.68)\end{array}$ & $\begin{array}{l}42.39^{d} \\
(7.74)\end{array}$ & $\begin{array}{l}69.51^{c} \\
(32.5)^{c}\end{array}$ & $\begin{array}{c}0.0341^{d} \\
(0.012)\end{array}$ & $\begin{array}{r}0.004 \epsilon \\
(0.006)\end{array}$ & $\begin{array}{c}0.1081^{d} \\
(0.017)\end{array}$ & $\begin{array}{l}-21.21^{c} \\
(10.3)\end{array}$ & $\begin{array}{l}236.2 \\
(144)\end{array}$ & 0.845 & 88 \\
\hline 2.2 & $\begin{array}{l}\text { Natural } \\
\text { gas } \\
\text { share }\end{array}$ & $\begin{array}{c}Q_{2} / Q \\
\times 1000\end{array}$ & & $\begin{array}{c}59.51^{d} \\
(10.03)\end{array}$ & $\begin{array}{c}-229.30^{\mathrm{d}} \\
(11.6)\end{array}$ & $\begin{array}{l}107.60^{c} \\
(48.8)\end{array}$ & $\begin{array}{r}0.0270 \\
(0.019)\end{array}$ & $\begin{array}{c}-0.014 C \\
(0.009)\end{array}$ & $\begin{array}{l}-0.0674^{c} \\
(0.025)\end{array}$ & $\begin{array}{c}-2.71 \\
(15.5)\end{array}$ & $\begin{array}{l}.215 .3 \\
(216)^{3}\end{array}$ & 0.819 & 88 \\
\hline 2.3 & $\begin{array}{l}\text { Share of } \\
\text { petroleum } \\
\text { products }\end{array}$ & $\begin{array}{c}Q_{3} / Q \\
\times 1000\end{array}$ & & $\begin{array}{l}15.53^{b} \\
(8.48)\end{array}$ & $\begin{array}{c}186.91^{\mathrm{d}} \\
9.83)\end{array}$ & $\begin{array}{c}-177.11^{\mathrm{d}} \\
(41.3)\end{array}$ & $\begin{array}{l}-0.0611^{d} \\
(0.016)\end{array}$ & $\begin{array}{c}0.0094 \\
(0.0076)\end{array}$ & $\begin{array}{l}-0.0407^{b} \\
(0.021)\end{array}$ & $\begin{array}{l}23.92^{b} \\
(13.1)\end{array}$ & $\begin{array}{l}548.5^{d} \\
(182)\end{array}$ & 0.879 & 88 \\
\hline
\end{tabular}

a Figures in parentheses are estimated standard errors; $R^{2}$ is the multiple coefficient of determination; and $D . F$. is the degrees of freedom.

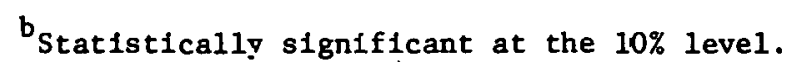

cstactistically significant at the $5 \%$ level.

${ }^{d}$ Statistically significant at the $1 \%$ level. 
By using the sample mean values, the aggregate-demand elasticities were computed to be -0.70 with respect to price and 0.41 with respect to income. Since the model is estimated from cross-sectional data, the resulting elasticities are generally interpreted as long-run elasticities. $^{14}$ The present estimate of price elasticity falls between the estimates obtained by Nissen-Knapp and Baughman-Joskow (Table 4). Our estimate of income elasticity is lower than both of theirs.

Since the estimated income elasticity is well below unity, raising incomes would not result in a proportional rise in energy demand. A greater proportion of additional income would be spent for other consumer goods and services if prices of energy remain constant. The estimated price elasticity is also below unity, implying that an increase could be expected in consumer expenditures on energy as the price of energy rises.

Table 4. Comparison of aggregate demand elasticities -

\begin{tabular}{lcc}
\hline \multicolumn{1}{c}{ Mode1 } & $\begin{array}{c}\text { Energy } \\
\text { price, } \\
\text { p }\end{array}$ & $\begin{array}{c}\text { Income, } \\
\text { I }\end{array}$ \\
\hline Present stúdy & -0.70 & 0.41 \\
Nissen-Knapp & -0.53 & 0.48 \\
Baughman-Joskow & -0.80 & 0.62 \\
\hline
\end{tabular}

Based on Individual market-share equations, we can compute the market-share elasticities. The price elasticities have the following general expression: 


$$
e_{i f}=\frac{\partial S_{i}}{\partial P_{j}} \frac{\bar{P}_{j}}{\bar{S}_{i}}=a_{i j} \frac{\bar{P}_{f}}{\bar{S}_{i}} \text { for } i, j=1,2,3 \text {, }
$$

where the "bar" Indicates the mean values of sample data. It can be shown that these market-share elasticities are equivalent to the conditional demand elasticlties. That is

$$
n_{i j}=\left.\frac{\partial Q_{1}}{\partial P_{j}} \frac{\bar{P}_{j}}{\bar{Q}_{i}}\right|_{\bar{Q}}=a_{i j} \frac{\bar{P}_{j}}{\bar{Q}_{i}} \quad \bar{Q}=a_{i j} \frac{\bar{P}_{j}}{\bar{s}_{i}}
$$

where aggregate demand $Q$ remains unchanged.

The matrix of computed conditional-demand elasticities is presented in Table 5. This elasticity matrix may be intepreted column by column. For example, elasticities in the first column show that an increase in electricity price by $1.0 \%$ would reduce long-run electric1ty demand by $1.34 \%$ and increase demands for natural gas and petroleum products by 1.0 and $0.3 \%$, respectively, holding aggregate energy demand unchanged. As noted in the matrix, the substitutability

Table 5. Estimated conditional demand elasticities given aggregate demanda

\begin{tabular}{lcccr}
\hline \multicolumn{1}{c}{ Type of fuel } & $\begin{array}{c}\text { Electricity } \\
\text { price, } \\
\mathrm{P}_{1}\end{array}$ & $\begin{array}{c}\text { Gas } \\
\text { price, } \\
\mathrm{P}_{2}\end{array}$ & $\begin{array}{c}\text { Oil } \\
\text { price, } \\
\mathrm{P}_{3}\end{array}$ & $\begin{array}{c}\text { Income, } \\
\text { I }\end{array}$ \\
\hline Electricity & -1.341 & 0.250 & 0.547 & 0.403 \\
Natural gas & 0.990 & -1.259 & 0.788 & 0.297 \\
Petroleum products & 0.275 & 1.090 & -1.378 & -0.715 \\
\hline
\end{tabular}

${ }^{a}$ Computed at sample means. 
between natural gas and petroleum products appears to be greater than efther between electricity and natural gas or between electricity and petroleum products. The estimated elasticity matrix is not symmetric. This lack of symetry can be explained by the fact that different fuels may be used for different purposes. For some end-use functions, substitution is simply not feasible or practical. For example, electricity used for lighting and air conditioning is generally considered nonsubstitutable, even though candles and gas air conditioners do exist.

From the standpoint of conserving end-use energy, it is of great interest to know the aggregate-demand elasticities with respect to individual fuel prices. These elasticities can be computed from our model. Differentiating Eq. (1) with respect to the price of fuel $j$ and using Eq. (2), we can derive:

$$
\frac{\partial Q}{\partial P_{j}}=a_{1}\left(S_{j}+\sum_{i=1}^{3} P_{i} a_{i j}\right) \text { for } i=1,2,3
$$

The elasticity can then be computed by

$$
e_{j}=\frac{Q}{P_{j}} \frac{\bar{P}_{j}}{\bar{Q}}=a_{1}\left(\bar{S}_{j}+\sum_{i=1}^{3} \bar{P}_{i} a_{i j}\right) \frac{\bar{P}_{j}}{\bar{Q}}
$$

These elasticities are computed to be -0.054 for electricity price, -0.264 for natural gas price, and -0.270 for oil price. The fact that these elasticities are all negative has an important implication for energy conservation. It suggests that pricing strategies can be effective instruments for achieving energy conservation. These elasticities 
are partial elasticities in the sense that their interpretation requires an assumption of holding all other factors constant. If the prices of other fuels increase simultaneously, as is generally the case, the resulting energy conservation would be greater than implied by these elasticities.

Another notable feature of our market-share approach is that the conventional demand elasticities are derivable analytically. To derive the own-price elasticity, we differentiate Eq. (2) with respect to $\mathrm{P}_{j}$ :

$$
\frac{\partial S_{j}}{\partial P_{j}}=\frac{1}{Q} \frac{\partial Q_{j}}{\partial P_{j}}-\frac{Q_{j}}{Q^{2}} \frac{\partial Q}{\partial P_{j}} .
$$

Substituting Eq. (7) into Eq. (9) and equating the resulting equation to $a_{i i}$, we obtain

$$
\frac{\partial Q_{j}}{\partial P_{j}}=a_{j j} Q+a_{1} s_{j}\left(s_{j}+\sum_{i=1}^{3} P_{i} a_{i j}\right) .
$$

Hence, the conventional own-price elasticity can be computed by

$$
E_{j j}=\frac{\partial Q_{j}}{\partial \bar{P}_{j}} \frac{\bar{P}_{j}}{\bar{Q}_{j}}=\left[a_{j f} \bar{Q}+a_{1} \bar{S}_{j}\left(\bar{S}_{j}+\sum_{i=1}^{3}{\overline{P_{i}}}_{i j}\right)\right] \frac{\bar{P}_{j}}{\bar{Q}_{j}}
$$

Note that Eq. (10) can be alternatively expressed by

$$
E_{j j}=\frac{\partial S_{j}}{\partial P_{j}} \frac{\bar{P}_{j}}{\bar{S}_{j}}+\frac{\partial Q}{\partial P_{j}} \frac{\bar{P}_{i}}{\bar{Q}}
$$


if the equality holds as follows:

$$
\bar{s}_{j}=\frac{\bar{Q}_{j}}{\bar{Q}} \text {. }
$$

Equation (11) states that the conventional-demand elasticity can be expressed as the sum of the market-share elasticity as previously determined in Eq. (6) and the aggregate-demand elasticity shown in Eq. (8). However, if we use the sample means for computation, the equality (12) does not hold in general. Hence, it is more appropriate to use Eq. (10) rather than Eq. (11), even though the differences are found to be very small.

Similarly, cross-price elasticity can be expressed as follows:

$$
E_{j k}=\frac{\partial Q_{j}}{\partial P_{k}} \frac{\bar{P}_{k}}{\bar{Q}_{j}}=\left[a_{j k} \bar{Q}+a_{1} \bar{S}_{j}\left(\bar{S}_{k}+\sum_{i=1}^{3} \bar{P}_{i} a_{i k}\right)\right] \frac{\bar{P}_{k}}{\bar{Q}_{j}}
$$

and income elasticity as

$$
E_{j I}=\frac{\partial Q_{j}}{\partial I} \frac{\bar{I}}{Q_{j}}=\left(a_{j 4} \bar{Q}+a_{2} \bar{S}_{j}\right) \frac{\bar{I}}{\bar{Q}_{j}} .
$$

The conventional-unconditional-demand elasticities computed at the mean values of sample data are presented in Table 6 . The estimates of own-price elasticities are all greater than 1.0 and this indicates that demands for all fuels are price elastic. Although the negative elasticity of natural gas price for electricity demand is not expected, its magnitude is small. This result does not seem too surprising, because most electricity demand studies have obtained either insignificant or 
small cross-price elasticities with respect to natural gas.

Considering natural gas demand, the two. cross-price elasticities are high, and their sum is almost equal to the own-price elasticity. These results imply that changes in prices of electricity and ofl would have substantial impacts on natural gas demand. However, if all fuel prices change by the same percentage, the impact on natural gas demand would be minimal because the own-price effect is offset by the cross-price effects. The same conclusion does not hold for electricity and petroleum products demands where the sum of cross-price elasticities is smaller than the ownprice elasticity, In the demand for petroleum products, natural gas is a much more important substitute than electricity. Furthermore, estimated income elasticities are positive but smaller than unity for electricity and natural gas. A negative income elasticity for petroleum products is not expected although the magnitude is small.

Table 6. Estimated conventional demand elasticites

\begin{tabular}{lcccc}
\hline \multicolumn{1}{c}{ Type of fuel } & $\begin{array}{c}\text { Electricity } \\
\text { price, } \\
\mathrm{P}_{1}\end{array}$ & $\begin{array}{c}\text { Gas } \\
\text { price, } \\
\mathrm{P}_{2}\end{array}$ & $\begin{array}{c}\text { Oil } \\
\text { price, } \\
\mathrm{P}_{3}\end{array}$ & $\begin{array}{c}\text { Income, } \\
\text { I }\end{array}$ \\
\hline Electricity & -1.461 & -0.015 & 0.290 & 0.856 \\
Natural gas & 0.919 & -1.495 & 0.508 & 0.698 \\
Petroleum products & 0.215 & 0.806 & -1.608 & -0.293 \\
\hline
\end{tabular}

The present estimatee of own-price elasticities are slightly higher than those estimates obtained by Baughman and Joskow ${ }^{7}$ and much higher than the estimates of Nissen and Knapp. ${ }^{6}$ Also, our estimates of crossprice elasticities. of the demands for natural gas and petroleum products 
are higher than those obtained by Baughman and Joskow. We note that they derived their demand elasticities using a simulation procedure, and one cannot be sure that the resulting estimates are independent of the particular assumptions they used in their simulations.

Our model was estimated assuming efficiency factors of 1.0 for electricity, 0.55 for natural gas, and 0.5 for petroleum products. Although these assumptions are the best to our knowledge, they are, by no means, absolutely accurate. It is, therefore, important to know how sensitive the resulting elasticity estimates are to these assumptions. To assess this sensitivity, we re-ran the regressions for four other alternative sets of efficiency assumptions. A detailed comparison of the resulting estimates of various elasticities is presented in Appendix B. The results show that the elasticity estimates are not sensitive to the assumptions made on end-use efficiencies within the range of uncertainty.

\section{Demand and Conservation of Primary Energy}

The analyses presented in Sections 2 and 3 dealt with energy used by households and commercial firms for performing various end-use functions. The elasticities obtained from these analyses measure the extent to which consumers respond to changes in economic and climatic factors in determining the amount of energy they actually use. However, these elasticities do not measure directly the response of demand to these exogeneous changes for primary energy sources. By primary energy, we mean the energy sources used to produce fuels for end-use. For example, coal, natural gas, oil, hydro-power, and uranium are used to generate electricity; electricity, natural gas, and oil are required fuels for 
drilling natural gas and ofl. To properly evaluate the potential for energy conservation, we need to examine the primary energy sources needed to meet the final demands for end-use fuels.

To analyze the primary energy demand in our model, we first must convert our end-use energy to primary energy, assuming fixed inputoutput relationships, and then compute the price elasticities for primary energy demand. From Eq. (3), we have

$$
q_{i}=\frac{Q_{1}}{n_{i}}
$$

where

$$
\begin{aligned}
q_{i}= & \text { reported quantity of fuel } i \text { without adjustment for } \\
& \text { end-use efficiency } \\
n_{1}= & \text { end-use efficiency factor of fuel } i \\
Q_{i}= & \text { adjusted quantity of fuel } i \text { used in our previous estimation. }
\end{aligned}
$$

Note that $q_{1}$ and $Q_{i}$ were expressed on a per-capita basis. Let $M_{i}$ be the amount of primary energy used to produce $q_{1}$. Furthermore, $M_{i}$ can be expressed as:

$$
M_{i}=\varepsilon_{i} q_{i}
$$

where $\varepsilon_{i}$ is the input-output coefficient measuring the amount of primary energy required to produce a unit of fuel $i$ for end-uses. Hence, the total primary energy demand can be expressed as

$$
M=\sum_{i=1}^{3} M_{i}=\sum_{i=1}^{3} \frac{\varepsilon_{i}}{n_{i}} Q_{i}
$$


In our formulation, the overall efficiency in using primary energy in homes and commercial bulldings can be defined as

$$
\delta_{i}=\frac{n_{1}}{\varepsilon_{1}}
$$

Equation (14) can then be rewritten as:

$$
M=\sum_{i=1}^{3} \frac{Q_{1}}{\delta_{i}}
$$

It must be noted that we are interested only in the total primary energy, disregarding the mixture of primary energy sources used for generating electricity or drilling natural gas. Herendeen and Bullard ${ }^{15}$ have shown that the overall input-output coefficients for converting primary energy to electricity, natural gas and petroleum products changed only slightly between 1963 and 1967 .

To examine the impacts of changes in fuel prices on primary energy demand, we differentiate $\mathrm{Eq}$. (16) with respect to the individual fuel prices:

$$
\frac{\partial M}{\partial P_{j}}=\sum_{i=1}^{3}\left(\frac{i}{\delta_{i}}\right) \frac{\partial Q_{i}}{\partial P_{j}}
$$

The price elasticities of the demand for primary energy can then be computed by

$$
\lambda_{j}=\frac{\partial M}{\partial P_{j}} \frac{\bar{P}_{j}}{\bar{M}}=\left[\sum_{i=1}^{3}\left(\frac{1}{\delta_{i}}\right) \frac{\partial Q_{1}}{\partial P_{j}}\right] \frac{\bar{P}_{j}}{\bar{M}} \quad \text { for } j=1,2,3 .
$$

For computing these elasticities, we note that the partial derivatives, $\frac{\partial Q_{1}}{\partial P_{j}}$ have been previously evaluated in Eqs. (9) and (10) using sample 
means. The total efficiency factors $\left(\delta_{i}\right)$ are computed based on the 1967 input-output coefficients estimated by Herendeen and Bullard. 15 These estimates are shown in Table 7. Accounting for the direct and indirect usage of energy in producing end-use fuels, electricity becomes the least efficient fuel with an overall efficiency of $26 \%$. The last figure needed for computing price elasticities is the mean value of $M$ which is obtained from Eq. (16) using the mean values of $Q_{1}$.

Table 7. Total efficiency factors by fuel type

\begin{tabular}{lccc}
$\begin{array}{c}\text { Type of } \\
\text { fuel }\end{array}$ & $\begin{array}{c}\text { End-use } \\
\text { efficiency } \\
\eta_{i}\end{array}$ & $\begin{array}{c}\text { Input-Output } \\
\text { foefficient } \\
\text { for converting }\end{array}$ & $\begin{array}{c}\text { Total } \\
\text { efimary energy } \\
\text { factor, } \\
\delta_{i}=\eta_{i} / \lambda_{i}\end{array}$ \\
\hline Electricity & 1.00 & $\varepsilon_{i}$ & 0.263 \\
Natural gas & 0.55 & 3.796 & 0.500 \\
Petroleum products & 0.50 & 1.101 & 0.414 \\
\hline
\end{tabular}

In Table 8 the resulting estimates of price elasticities using Eq. (17) are compared with the estimates previously obtained using Eq. (8) for total end-use energy. A striking difference was found on the estimated elasticity of electricity price. The magnitude of the electricity price elasticity $(-0.33)$ for primary energy demand is much higher than that of the prices of natural gas and oil, while it is the lowest $(-0.05)^{\circ}$ among the three price elasticities for end-use energy demand. This is clearly due to the fact that the total efficiency for using electricity is much lower than that of natural gas and petroleum products. The resulte show that raising electricity prices would be more effective in 
Table 8. Comparison of estimated price elasticities

for total end-use energy and primary energy

\begin{tabular}{|c|c|c|c|}
\hline Type of demand & $\begin{array}{c}\text { Electricity } \\
\text { price, } \\
\mathrm{P}_{1}\end{array}$ & $\begin{array}{l}\text { Gas } \\
\text { price, } \\
\mathrm{P}_{2}\end{array}$ & $\begin{array}{c}011 \\
\text { price, } \\
\mathrm{P}_{3}\end{array}$ \\
\hline End-use energy & -0.054 & -0.264 & -0.270 \\
\hline Primary energy & -0.330 & -0.157 & -0.224 \\
\hline
\end{tabular}

conserving primary energy than raising prices of natural gas and ofl. This is, of course, in sharp contrast to the conclusion reached for enduse energy demand which showed the opposite. These results are not contradictory; rather, they show that it is essential to distinguish between end-use energy and primary energy for making policy decisions concerning energy conservation.

\section{Conclustons}

This study shows that aggregate end-use energy demand in the residential/commercial sector has a price elasticity of -0.7 , while individual fuel demands are all price elastic in the long run. Furthermore, changes in the price of a particular fuel would affect its demand more than the aggregate energy demand because of interfuel substitution. For example, an increase of $1 \%$ in electricity price would reduce electricity demand by $1.4 \%$ and reduce total end-use energy demand by $0.1 \%$. With a $1 \%$ increase In price of natural gas, the resulting demand reductions for natural gas and for total end-use energy would be 1.5 and $0.2 \%$ respectively. A $1 \%$ increase in the price of oil would reduce demand by $1.6 \%$ and the aggregate end-use energy demand by $0.3 \%$. Hence, raising petroleum prices appears to have the strongest potential for conserving end-use energy. 
When primary energy is considered, the results show that the elasticity of electricity price is higher than that of prices of natural gas and oil. This higher elasticity indicates that increasing the price of electricity has a greater impact on reducing demand for primary energy. The study concludes that it is essential to distinguish primary energy from end-use energy for making policy decisions.

The model constructed in this paper explains the consumer's response to changes in various explanatory variables. Since cross-sectional data were used for the estimations, the results characterize interstate variation as well as behavioral relationships. There are potential causes that may induce changes in the demand structure in the future. For example, new technologies such as solar heating and the Annual Cycle Energy System (ACES) may be widely adopted. Also, there may be significant changes in life styles so that people prefer smaller and multiunit housing. Therefore, the energy conservation resulting from higher prices may be greater than our historical elasticities indicate. The fact that consumers do respond to price changes, as shown in this and other studies, suggests that significant potential exists for adopting energy conserving technologies in this era of increasing energy prices.

The model has at least two limitations regarding 1ts usefulness for forecasting. First, a model based on cross-sectional analysis provides only estimates of long-run demand elasticities. In forecasting, it is necessary to deal with both short- and long-run effects. Second, although our 11near model assures that the estimated marker-shares always sum to unity, it does not guarantee that the estimated shares are all positive. Despite these limitations, the model gives a better analytical 
insight into the demand structure than other models that use log or logit form.

Finally, we should point out also that our model does not deal with interrelationships between the price of electricity and the prices of natural gas and oil. Since natural gas and petroleum products have been among the major energy sources for generating electricity, changes in prices of natural gas and oil will affect the price of electricity. Hence, any policy instruments, such as the deregulation of the prices of natural gas and oil designed to affect prices of natural gas and oil, will also affect the price of electricity. We anticipate, however, that the significance of these realtionships will reduce in the future when the nation possibly moves toward using more abundant energy sources such as coal and nuclear power for electric generation. 


\section{Appendix A: Data}

Annual data for 48. states (excludes Hawal1 and Alaska) for 1971 , and 1972 were used for this study. Data on total energy consumption of electricity, natural gas, and petroleum products were obtained from the U.S. Department of Interior (Fuel and Energy Data, United States by States and Regions, 2972, Bureau of Mines Information Circular 8647, 1974; and United States Energy Fact Sheets, 2977, February 1973). Average electrictty prices were computed by dividing revenues by sales of electricity by states published by Edison Electric Institute (Statistical Yearbook of the Electric Utility Industry, for 1971 and 1972). Similarly, average natrual gas prices were computed from the revenues and sales data published by American Gas Association (Gas Facts, 1971 and 1972). Data on No. 2 oil prices were obtained from the Platt's Oil Price Handbook and Oilmanac for 1971 and 1972 (McGraw-Hill, Inc., New York). Market spot (or termina1) price is available for only 56 major cities. For those states without any reported city, data for an adjacent state were used. We adjusted these terminal prices to retail prices by assuming a fixed percent of markup (65\%).

State data on heating degree days (average welghted population over divisions) were obtained from the National Climatic Center, Asheville, N.C. ("Monthly Heating Degree Days by State and Season," Job No. 14624, November 13, 1973). Data on cooling degree days by city were obtained from National Oceanic and Atmospheric Administration (Climulological Data, National Summary, December 1971 and December 1972). City data were averaged to yield data for states. 
Data on personal income were obtained from the Survey of Current Business, Apr11 1974 (U.S. Department of Commerce). Population data were taken from the Current Population Reports (U.S. Bureau of the Census). Finally, all prices and income variables were deflated by the costof-living index. The 1970 state Indices derfved by Anderson ${ }^{16}$ were adjusted by the national consumer price index to obtain appropriate deflators for 1971 and 1972. 


\section{Appendix B: Comparison of the Estimated Elasticities for}

\section{Alternative Assumptions on End-Use Efficiency}

This appendix presents a detailed comparison of various sets of elasticity estimates using alternative assumptions on end-use efficiency. As stated previously, the base case assumed efficiency factors of 1.0 for electricity, 0.55 for natural gas, and 0.5 for petroleum products. Four other alternative assumptions were made for comparison. Based on these alternative assumptions, the model was re-estimated and elasticities were computed at the mean values using the formulas presented in the text.

Table B.1 compares the aggregate demand elasticities, and Table B.2 presents the aggregate demand elasticities with respect to individual fuel prices. The conventional demand elasticities are detailed in Table B.3. The results show that the model is extremely insensitive to the assumptions used within the range of uncertainty. However, there exist some regularities. For example, in Table B.1 it is found that the larger the efficiency factors are for natural gas and o1l, the smaller the price elasticity and the greater is the income elasticity. 
Table B.1. Comparison of aggregate demand elasticities

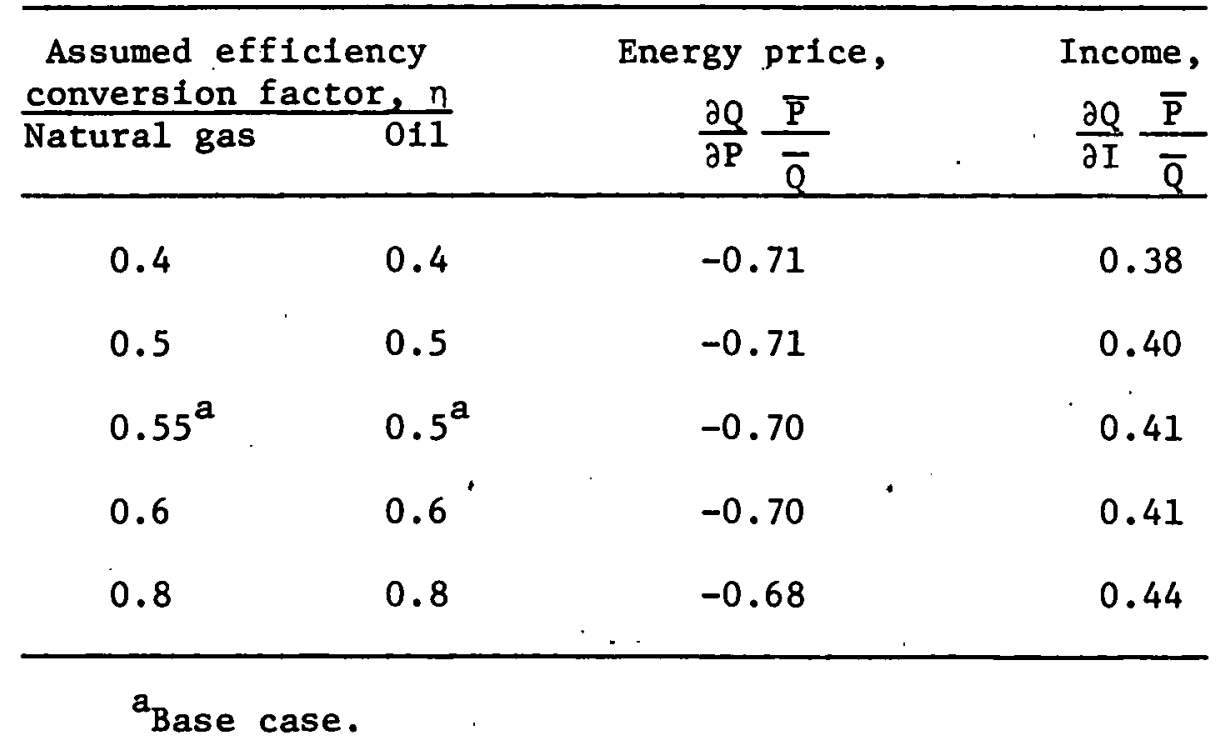

Table B.2. Comparison of aggregate demand elasticities with respect to individual fuel prices ${ }^{a}$

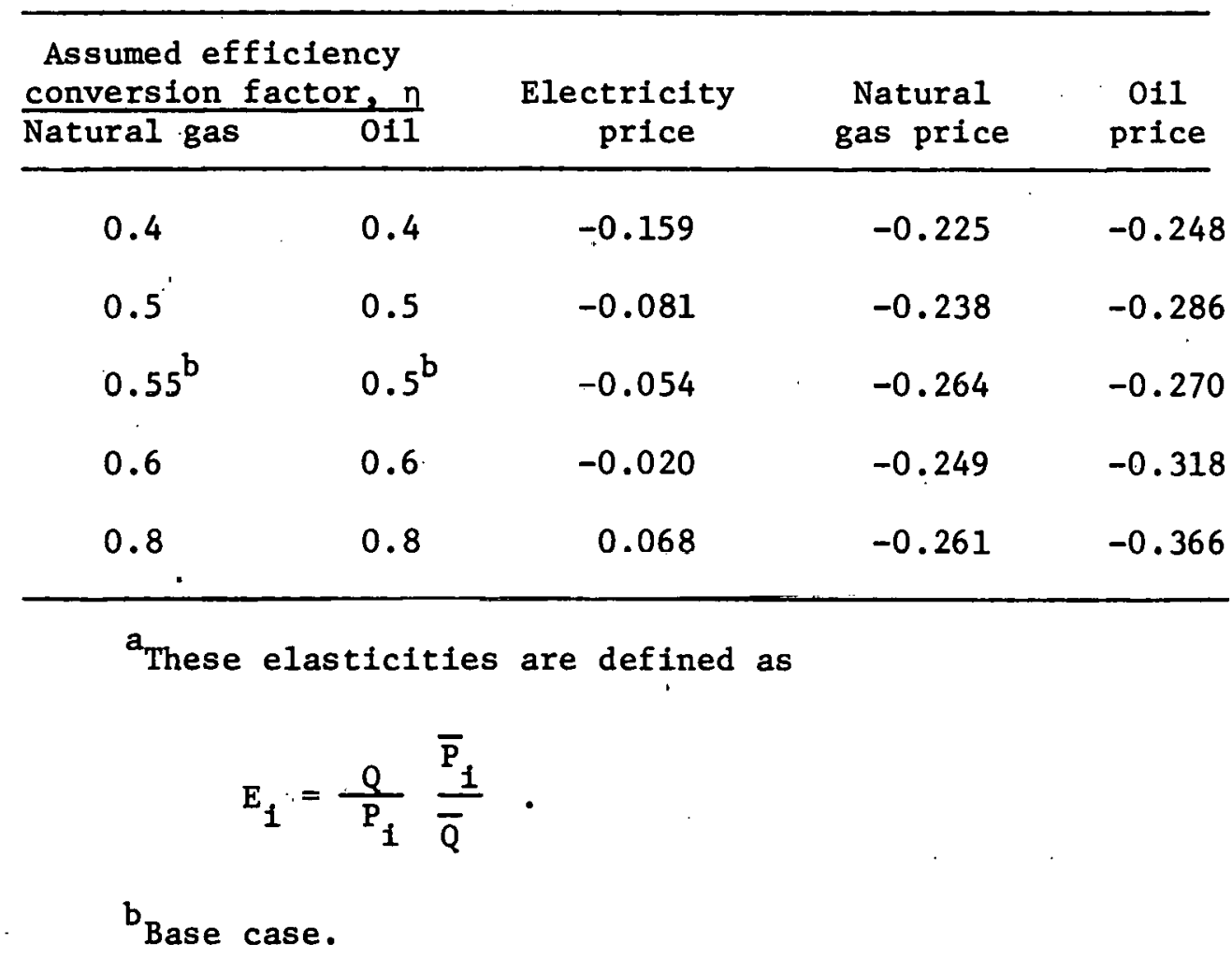


Table B.3 Comparison of the conventional demand elasticities for 1ndividual fuels

\begin{tabular}{|c|c|c|c|c|c|c|}
\hline $\begin{array}{l}\text { Assumed ef } \\
\text { converston } \\
\text { Nacural gas }\end{array}$ & $\begin{array}{l}\text { ency } \\
011\end{array}$ & Type of fue 1 & $\begin{array}{l}\text { Electric1ty } \\
\text { price }\end{array}$ & $\begin{array}{r}\mathrm{Gas}^{\mathrm{a}} \\
\text { price }\end{array}$ & $\begin{array}{r}011^{a} \\
\text { price }\end{array}$ & Income \\
\hline 0.4 & 0.4 & $\begin{array}{l}\text { Electricity } \\
\text { Natural } \\
\text { Petroleum products }\end{array}$ & $\begin{array}{r}-1.385 \\
0.918 \\
0.219\end{array}$ & $\begin{array}{r}-0.045 \\
-1.509 \\
0.801\end{array}$ & $\begin{array}{r}0.237 \\
0.597 \\
-1.617\end{array}$ & $\begin{array}{r}0.731 \\
0.704 \\
-0.325\end{array}$ \\
\hline 0.5 & 0.5 & $\begin{array}{l}\text { Electricity } \\
\text { Natural gas } \\
\text { Petroleum products }\end{array}$ & $\begin{array}{r}-1.444 \\
0.931 \\
0.194\end{array}$ & $\begin{array}{r}-0.027 \\
1.502 \\
0.781\end{array}$ & $\begin{array}{r}0.280 \\
0.557 \\
-1.615\end{array}$ & $\begin{array}{r}0.824 \\
0.693 \\
-0.276\end{array}$ \\
\hline $0.35^{c}$. & $0.5^{c}$ & $\begin{array}{l}\text { Flootrlefty } \\
\text { Natural gas } \\
\text { Petroleum products }\end{array}$ & $\begin{array}{r}-1.461 \\
0.919 \\
0.215\end{array}$ & $\begin{array}{r}-0.015 \\
-1.495 \\
0.806\end{array}$ & $\begin{array}{r}0.290 \\
0.508 \\
-1.608\end{array}$ & $\begin{array}{r}0.856 \\
U .698 \\
-0.293\end{array}$ \\
\hline 0.6 & 0.6 & $\begin{array}{l}\text { Rlectriclty } \\
\text { Natural gas } \\
\text { Petroleum products }\end{array}$ & $\begin{array}{r}-1.486 \\
0.946 \\
0.179\end{array}$ & $\begin{array}{r}-0.011 \\
-1.498 \\
0.768\end{array}$ & $\begin{array}{r}0.320 \\
0.523 \\
-1.615\end{array}$ & $\begin{array}{r}0.910 \\
0.691 \\
-0.236\end{array}$ \\
\hline 0.8 & 0.8 & $\begin{array}{l}\text { Electricity } \\
\text { Natural gas } \\
\text { Petroleum products }\end{array}$ & $\begin{array}{r}-1.559 \\
0.959 \\
0.150\end{array}$ & $\begin{array}{r}0.020 \\
\times \quad-1.489 \\
0.755\end{array}$ & $\begin{array}{r}0.297 \\
0.473 \\
-1.612\end{array}$ & $\begin{array}{r}1.057 \\
0.694 \\
-0.169\end{array}$ \\
\hline
\end{tabular}

a The price elasticities are defined as

$$
E_{j k}+\frac{\partial Q_{j}}{\partial P_{k}} \frac{\bar{P}_{k}}{\bar{Q}_{j}} \text { for } j, k=1,2,3 \text {. }
$$

$b_{\text {The Income elasticlty is defined as }}$

$$
K_{j}=\frac{\partial Q_{1}}{\partial I} \frac{\bar{I}}{\bar{Q}_{j}} .
$$

Base case. 
Footnotes and References

1. Duane Chapman, Timothy Tyrre11, and Timothy Mount, "Electricity Demand Growth and the Energy Crisis," Science 178, 703-708 (November 17, 1972).

2. E. C. Hise and A. S. Holman, Heat Balance and Efficiency Measurements of Central, Forced-Air, Residential Gas Fumaces, Oak Ridge National Laboratory, report ORNL-NSF-EP-88, October 1975.

3. E. C. Hise, Seasonal Fuel Utilization Efficiency of Residential Heating Systems, Oak RIdge Naional Laboratory, report ORNL-NSFEP-82, Apri1 1975.

4. Initially, we also included coal in the model. As it turned out, the price of coal was never significant in the share equations of the other three fuels, and the prices of other fuels, were not significant in the share equation for coal. Since the consumption of coal is of minimal magnitude in the residential and commercial sectors, we excluded this component from our analysis.

5. J. Muller and R. Bass, "An Interim Report on Some Ways of Conserving 0i1," mineographed, Federal Energy Office, Washington, D.C. October 1, 1975.

6. David H. Nissen and David H. Knapp, "A Regional Model of Interfuel Substitution," presented at the SIMS Research Application Conference on Energy, Alta, Utah, July 7-11, 1975.

7. Martin L. Baughman and Paul L. Joskow, "Energy Consumption and Fuel Choice by Residential and Commercial Consumers in the United States," Massachusetts Institute of Technology, May 20, 1975.

8. For a more detailed discussion and critique of this type of logit specification, see J. S. Hausman, "Project Independence Report: An Appraisal of U.S. Energy Needs up to 1985," BelZ J. Econ. 6, 517-551 (Autumn 1975).

9. A. Zellner, "An Efficient Method of Estimating Seemingly Unrelated regressions and Tests for Aggregation Bias," J. Amer. Stat. Assoc. 57, 348-368 (June 1962).

10. Ernst R. Berndt and David 0. Wood, "Technology, Prices, and the Derived Demand for Energy," Rev. Econ. Stat. 52, 259-268

(August 1975).

11. C. R. Rao, Linear Statistical Inference and Its Applications, New York, : Wiley, 1965. 
12. R. S. Pindyck and D. L. Rubinfeld, Econometric Models and Economice Forecasts, New York, McGraw-H111, 1976.

13. Although we used data for two years, the model is expected to explain primarily cross-sectional differences. Indeed, this was found to be the case. As we estimated the same model (without D) for 1971 and 1972 separately, the resulting estimates were very similar.

14. This is true as a general tendency. But cross-section data, especially in situations where durable goods are involved, can still reflect short-run varlation. See H. S. Houthakker and L. D. Taylor, Consumer Demand in the United States, Harvard University Press, 1970, pp. 275-280.

15. Robert A. Herendeen and Clark W. Bullard, III, "Energy Cost of Goods and Services, 1963 and 1967," Center for Advanced Computation, CAC Document No. 140, University of Illinois at UrbanaUhampalgn, Nuvemler 1974.

16. Kent P. Anderson, Residential Energy Use: An Econometric Analysis, Rand Corporation, report R-1297-NSF, October 1973. 


\section{THIS PAGE}

\section{WAS INTENTIONALLY \\ LEFT BLANK}


ORNL/TM-5557

Internal Distribution

1. S. I. Auerbach

2. S. E. Beall

3. D. J. Bjornstad

4. D. Brooks

5. J. R. Buchanan

6. R. S. Carlsmith

7. W. S. Chern

8. F. L. Culler

9. J. G. Delene

10. A. P. Fraas

11. W. Fulkerson

12. G. S. Gill

13. W. R. Griffith

14. M. Guthrie

15. N. Hardin

16. V. 0. Haynes

17. E. A. Hirst

18. P. L. Johnson

19. S. I. Kaplan

20. R. S. Livingston

21. J. W. Michel

22. W. R. Mixon

23. J. C. Moyers
24. E. A. Nephew

25. H. Postma

26. M. W. Rosenthal

27. T. H. Row

28. R. L. Spore

29. E. G. Struxness

30. D. B. Trauger

31. G. U. Ulrikson

32. A. M. Weinberg

33. A. Zucker

34. Biology Division Laboratory (1)

35-36. Central Research Library (2)

37. Institute of Energy Analysis, ORAU

38. Laboratory Records, ORNL R.C. (1)

39-41. Laboratory Records Department (3)

42. ORNL - Y-12 'lechnicàl L1brary Document Reference Section (1)

43. ORNL Patent Office (1)

44. Research and Technical Support Division, ERDA-ORO (1)

45-185. Energy Conservation Section (140)

\section{External Distribution}

186-472. External Energy Conservation Distribution Mailing List (287)

473-500. Technical Information Center, ERDA, P. O. Box 62, Oak Ridge, TN (27) 